Article

\title{
Identification of Interleukin-8-Reducing Lead Compounds Based on SAR Studies on Dihydrochalcone-Related Compounds in Human Gingival Fibroblasts (HGF-1 cells) In Vitro
}

\author{
Katharina Schueller ${ }^{1}$, Joachim Hans ${ }^{2}$, Stefanie Pfeiffer ${ }^{1}$, Jessica Walker ${ }^{1,3, *}$, Jakob P. Ley ${ }^{2}$ and \\ Veronika Somoza ${ }^{1,4}$ \\ 1 Department of Physiological Chemistry, Faculty of Chemistry, University of Vienna, Althanstraße 14, \\ 1090 Vienna, Austria; Katharina.zakovsek@gmx.at (K.S.); Stefanie.pfeiffer88@gmx.at (S.P.); \\ veronika.somoza@univie.ac.at (V.S.) \\ 2 Symrise AG, Mühlenfeldstraße, 37603 Holzminden, Germany; joachim.hans@symrise.com (J.H.); \\ jakob.ley@symrise.com (J.P.L.) \\ 3 Department of Analytical Chemistry, Faculty of Chemistry, University of Vienna, Währinger Straße 38, \\ 1090 Vienna, Austria \\ 4 Leibniz Institute for Food Systems Biology at the Technical University of Munich, Lise-Meitner-Straße 34, \\ 85354 Freising, Germany \\ * Correspondence: jessica.walker@univie.ac.at; Tel.: +43-4277-52337; Fax: +43-1-4277-852337
}

Academic Editor: Peter J. Rutledge

Received: 31 January 2020; Accepted: 16 March 2020; Published: 18 March 2020

\begin{abstract}
Background: In order to identify potential activities against periodontal diseases, eighteen dihydrochalcones and structurally related compounds were tested in an established biological in vitro cell model of periodontal inflammation using human gingival fibroblasts (HGF-1 cells). Methods: Subsequently to co-incubation of HGF-1 cells with a bacterial endotoxin (Porphyromonas gingivalis lipopolysaccharide, $p g$ LPS) and each individual dihydrochalcone in a concentration range of $1 \mu \mathrm{M}$ to $100 \mu \mathrm{M}$, gene expression of interleukin-8 (IL-8) was determined by qPCR and cellular interleukin-8 (IL-8) release by ELISA. Results: Structure-activity analysis based on the dihydrochalcone backbone and various substitution patterns at its aromatic ring revealed moieties $2^{\prime}, 4,4^{\prime}, 6^{\prime}$-tetrahydroxy 3-methoxydihydrochalcone (7) to be the most effective anti-inflammatory compound, reducing the $p g$ LPS-induced IL-8 release concentration between $1 \mu \mathrm{M}$ and $100 \mu \mathrm{M}$ up to $94 \%$. In general, a 2,4,6-trihydroxy substitution at the A-ring and concomitant vanilloyl (4-hydroxy-3-methoxy) pattern at the B-ring revealed to be preferable for IL-8 release inhibition. Furthermore, the introduction of an electronegative atom in the A,B-linker chain led to an increased anti-inflammatory activity, shown by the potency of 4-hydroxybenzoic acid $N$-vanillylamide (13). Conclusions: Our data may be feasible to be used for further lead structure designs for the development of potent anti-inflammatory additives in oral care products.
\end{abstract}

Keywords: structure-activity relationship; inflammation; dihydrochalcones; IL-8; HGF-1 cells

\section{Introduction}

Periodontal diseases are a significant health problem with a high prevalence and incidence worldwide, and have a major impact on the quality of life [1]. Gingivitis is the first stage in the development of periodontitis and starts at the free gingival margin, with a reversible inflammatory immune reaction to accumulated dental plaque caused by a lack of oral hygiene [2]. Clinical signs of gingivitis are changes of tissue color and texture, bleeding upon gentle probing and over-production of 
crevicular fluid [2]. If untreated, the persisting immune reaction to plaque bacteria can promote loss of the attaching tissue and the formation of periodontal pockets [2]. In the worst case, periodontitis can peak in the infestation of the alveolar bone and tooth loss [2]. In the Netherlands, a western country with high hygienic standards, dentists surveyed that $32 \%$ of their patients suffered from gingivitis [3]. One strategy to counteract periodontal inflammation is the addition of anti-inflammatory compounds to oral care products. For example, the authors previously showed an anti-inflammatory impact on oral inflammation by the addition of a plant extract to chewing gum [4].

Especially, natural compounds have been used in various food and cosmetic products due to their beneficial health effects. Neohesperidin dihydrochalcone (NHDC, 1), a high impact sweetener approved for the application in foods, beverages, and oral hygiene products, is structurally related to polyphenols, which are widely known for their anti-inflammatory activity [5-7]. NHDC, some related dihydrochalcones, and the glycosylated compound hesperidin (3) have been tested for their anti-inflammatory potential [8-11]. The dihydrochalcone phloretin, naturally found in apples, is known to inhibit the mRNA expression of pro-inflammatory genes, such as nuclear factor kappa $\mathrm{B}$ (Nf-kB) or interleukin-8 (IL-8), in human cell lines [12] and reduced the lipopolysaccharide-induced inflammatory response in a murine cell model of systemic inflammation [13]. However, there are neither data on periodontal disease models nor in-depth studies on structural requirements for superior anti-inflammatory activity of dihydrochalcones and related compounds.

The screening of an anti-inflammatory potential of dihydrochalcones with regards to oral inflammation requires an appropriate model system. One of the bacteria strongly associated with periodontal diseases is the gram-negative germ Porphyromonas gingivalis ( $p g$ ) [14]. Bacteria and their side-products (endotoxins and membrane components) are recognized by cells via pattern recognition receptors, with toll-like receptors (TLR) among those [14]. Lipopolysaccharides (LPS) are a type of bacterial endotoxins from the outer bacterial membrane and trigger TLR-mediated activation of transcription factor $\mathrm{Nf}-\mathrm{kB}$ in gum tissue, resulting in the release of inflammatory cytokines and chemokines [14]. IL-8, belonging to the family of CXC motif chemokines, is essential in the response to infection and injury by activating various cell types surrounding the inflamed site and recruiting immune cells from the blood stream [15]. The in vitro release of IL-8 in human gingival fibroblasts (HGF-1), a well-established model of gum inflammation, can be up-regulated to up to 40-fold by stimuli like Porphyromonas gingivalis lipopolysaccharide ( $p g$ LPS) [6]. The addition of anti-inflammatory active compounds in this model decreased the LPS-stimulated release of pro-inflammatory markers, like IL-6, IL-8, and monocyte chemotactic protein 1 (MCP-1) $[6,16,17]$. In order to continuously impair gum inflammation, caused by plaque bacteria, the supplementation of oral hygiene products with antimicrobial and anti-inflammatory natural and synthetic substances is a common strategy in the prevention and treatment of gum diseases [18-20]. In addition, for hesperitin, an aglycone structurally related to neohesperdin, the mode of its anti-inflammatory activity has been investigated intensively, demonstrating both, a modulation of the TLR4/Nf- $\mathrm{BB}$ signaling pathway [21] as well as an impact on the mitogen-activated protein kinase pathway [22]. Both pathways are known to be involved in the inflammatory response to lipopolysaccharides $[23,24]$ and are targeted by anti-inflammatory polyphenols $[25,26]$. The red-wine polyphenol resveratrol possesses its anti-inflammatory activity by inhibiting these pathways, potentially by directly interacting with TLR4 [27], suggesting a potential mechanism of action for anti-inflammatory test compounds.

The aim of the present study was the identification of the anti-inflammatory effects of polyphenolic compounds regarding oral inflammation. Based on the dihydrochalcone structure of 1, a known anti-inflammatory compound, we developed a substance library consisting of 18 compounds (Table 1) and subjected them to testing in an in vitro model of $p g$ LPS-induced inflammation in human gingival fibroblasts (HGF-1) for the reduction of IL-8 release as a key biomarker of the immune response. 
Table 1. Basic core structures with labels, numbering, common names (if applicable), structures, and calculated areas under the curve (AUCs) as the sum of trapezoid areas under the dose-response curve of interleukin-8 (IL-8) values (normalized to Porphyromonas gingivalis lipopolysaccharide (pgLPS) control) from $1 \mu \mathrm{M}$ to $100 \mu \mathrm{M}$ for tested substances $\mathbf{1 - 1 8}$.

\begin{tabular}{|c|c|c|c|}
\hline No & Common Name & Structure & $\begin{array}{c}\text { AUC }(1-100 \mu M) \\
\text { Mean } \pm \text { SD }\end{array}$ \\
\hline & A,C-bicyclic system with solitary Bring & & - \\
\hline- & A-ring-linker-B-ring system & & - \\
\hline 1 & Neohesperidin dihydrochalcone & & $7930 \pm 1730$ \\
\hline 2 & Neohesperidin & & $9111 \pm 2497$ \\
\hline 3 & Hesperidin & & $6648 \pm 1589$ \\
\hline 4 & Hesperetin & & $7740 \pm 1782$ \\
\hline 5 & Liquiritigenin & & $8942 \pm 2450$ \\
\hline 6 & Hesperetin dihydrochalcone & & $5945 \pm 969$ \\
\hline 7 & $\begin{array}{c}2^{\prime}, 4,4^{\prime}, 6^{\prime} \text {-tetrahydroxy } \\
\text { 3-methoxydihydrochalcone }\end{array}$ & & $3303 \pm 816$ \\
\hline 8 & Phloretin & & $7872 \pm 629$ \\
\hline 9 & Davidigenin & & $6527 \pm 1625$ \\
\hline 10 & $\begin{array}{c}2^{\prime}, 4,4^{\prime} \text {-trihydroxy } \\
\text { 3-methoxydihydrochalcone }\end{array}$ & & $5052 \pm 596$ \\
\hline
\end{tabular}


Table 1. Cont.

\begin{tabular}{|c|c|c|c|}
\hline No & Common Name & Structure & $\begin{array}{c}\text { AUC }(1-100 \mu M) \\
\text { Mean } \pm \text { SD }\end{array}$ \\
\hline 11 & $\begin{array}{c}2^{\prime}, 3,4^{\prime} \text {-trihydroxy } \\
\text { 4-methoxydihydrochalcone }\end{array}$ & & $5626 \pm 614$ \\
\hline 12 & $\begin{array}{c}\text { 4,4'-dihydroxy } \\
\text { 3-methoxydihydrochalcone- }\end{array}$ & & $6940 \pm 950$ \\
\hline 13 & $\begin{array}{l}\text { 4-hydroxybenzoic acid } \\
N \text {-vanillylamide }\end{array}$ & & $4363 \pm 696$ \\
\hline 14 & $\begin{array}{c}\text { 2,4-dihydroxybenzoic acid } \\
N \text {-vanillylamide }\end{array}$ & & $7558 \pm 973$ \\
\hline 15 & $3^{\prime}, 5,7$, -trihydroxy $4^{\prime}$-methoxyflavan & & $7341 \pm 942$ \\
\hline 16 & $3^{\prime}, 7$-dihydroxy $4^{\prime}$-methoxyflavan & & $9063 \pm 1511$ \\
\hline 17 & $\begin{array}{c}3^{\prime} \text { methoxy } \\
2,4,4^{\prime} \text {-trihydroxydeoxybenzoin }\end{array}$ & & $6378 \pm 1389$ \\
\hline 18 & Resveratrol & & $6512 \pm 1761$ \\
\hline
\end{tabular}

\section{Results}

In this report, structure-activity relationships of dihydrochalcones and related substances are presented, and we propose two structural patterns for IL-8 release reduction to be used as lead structures for future studies.

\subsection{Compound Category Effectiveness}

Substances (Table 1) were tested at five concentrations ranging between $1 \mu \mathrm{M}$ and $100 \mu \mathrm{M}$ in an in vitro model previously published [28], with the modifications described in the method section. After $6 \mathrm{~h}$ of co-incubation with $p g$ LPS and the test compound, IL-8 release was measured in the supernatants, and the calculated percentage change was compared to the inflammatory stimulus $p g L P S$ alone. Cell vitality was determined using an MTT assay upon $6 \mathrm{~h}$ incubation of the HGF-1 cells with $10 \mathrm{ng} / \mathrm{mL}$ pgLPS and 1-100 $\mu \mathrm{M}$ of each compound. Treated HGF-1 cells did not show any significant reduction of cell vitality compared to the respective solvent control (0.1\% DMSO) as shown in Figure 1 for the compounds 1-18 in the highest tested concentration of $100 \mu \mathrm{M}$ co-incubated with $10 \mathrm{ng} / \mathrm{mL} p g \mathrm{LPS}$. Therefore, the effects of the tested compounds measured on IL-8 release are not affected by cytotoxic effects. Graphs for the release of IL-8 after incubation with substances $\mathbf{1}$ to $\mathbf{1 8}$ are part of the supporting information (Figure 4, Figures S2 and S3). Subsequently, the area under the curve (AUC) was calculated 
for each substance $\left(\mathrm{AUC}_{1, \ldots, 18}\right)$ and categories of substances $\left(\mathrm{AUC}_{\text {median }}\right)$ as the sum of trapezoid areas between data points.

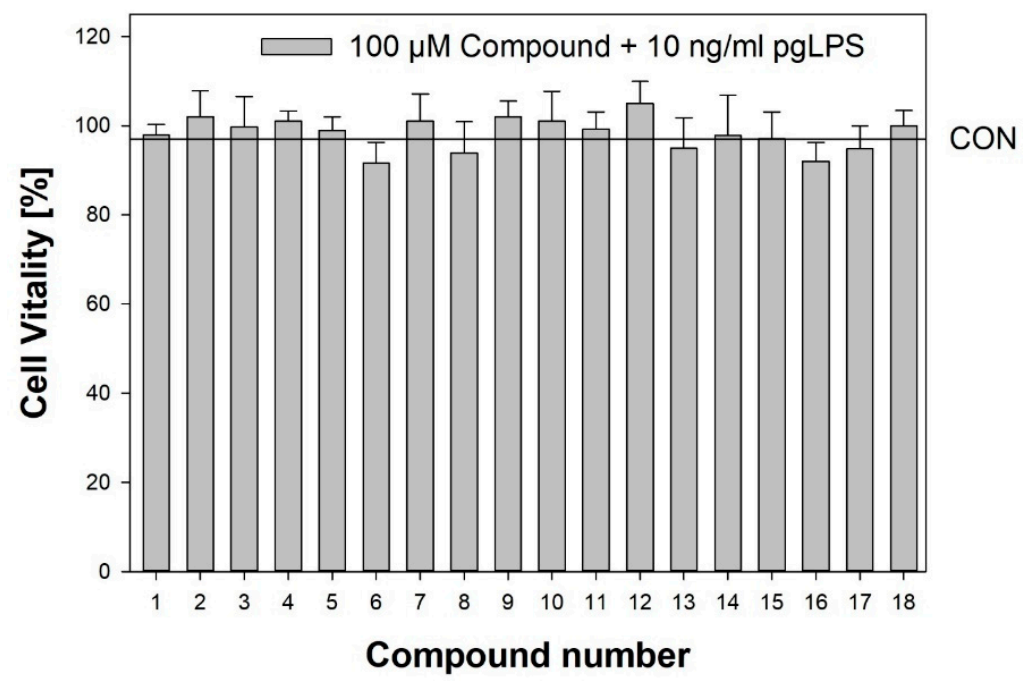

Figure 1. Cell vitality upon $6 \mathrm{~h}$ incubation of human gingival fibroblasts (HGF-1) cells with 10 $\mathrm{ng} / \mathrm{mL}$ lipopolysaccharides (LPS) and $100 \mu \mathrm{M}$ of the respective compound. Shown are average \pm SD compared to untreated cells. The horizontal line marks the vitality of cells treated with $0.1 \%$ DMSO only. Significant differences between treatment and control were tested using the Student's $t$-test.

The difference between single compound values $\left(\Delta \mathrm{AUC}_{\mathrm{x} / \mathrm{y}}\right)$ or between category median values $\left(\triangle \mathrm{AUC}_{\text {median(catx)/median(caty) }}\right)$ was used for the comparison of effectiveness. Low AUCs therefore mean high bioactivity, and the closer $\triangle \mathrm{AUC}_{\mathrm{x} / \mathrm{y}}$ is to zero, the less the substances differ in bioactivity. As our first step in defining SAR, substances were categorized by core structure, resulting in seven structural subclasses (Figure 2), where the class of diphenylethanons (DPE) and stilbenes (STB) only consisted of one compound each (17 and $\mathbf{1 8}$, respectively).

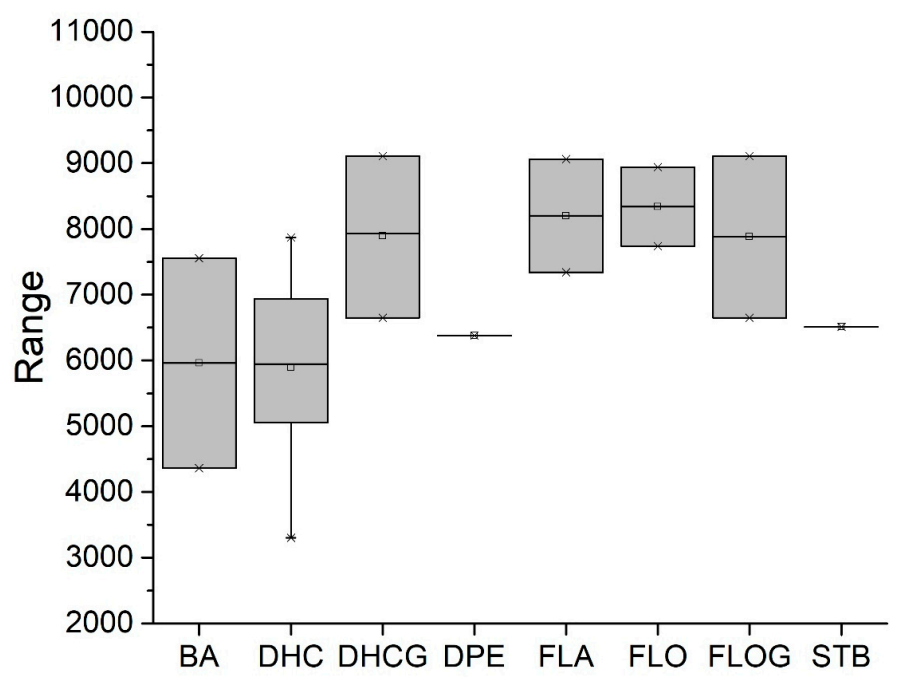

Figure 2. Comparison of the reduction of IL-8 release in $p g$ LPS-stimulated HGF-1 cells among groups of the tested compounds (1 to 18) with different core scaffolds. Depicted are boxplots (min, $\mathrm{Q}_{0.25}$, median, $\mathrm{Q}_{0.75}$, max) of the individual AUCs in the substance groups. Substance groups are N-benzyl-benzamides (BA; $n=2$; compounds 13 and 14, $\left.\mathrm{AUC}_{\text {median }}=5928\right)$, dihydrochalcones (DHC; $\left.n=7 ; \mathbf{6}-12, \mathrm{AUC}_{\text {median }}=5738\right)$, dihydrochalcone glycosides $\left(\mathrm{DHCG} ; n=3 ; \mathbf{1}-\mathbf{3}, \mathrm{AUC}_{\text {median }}=7766\right)$, diphenylethanone (DPE; $n=1 ; 17, \mathrm{AUC}=6378)$, flavans (FLA; $n=2 ; 15$ and 16, $\mathrm{AUC}_{\text {median }}=8090$ ), flavanones (FLO; $n=2 ; 4$ and $\left.5, \mathrm{AUC}_{\text {median }}=8105\right)$, and stilbenoid (ST; $\left.n=1 ; \mathbf{1 8}, \mathrm{AUC}=6512\right)$. 
Considering only groups with at least two compounds, Dihydrochalcones (DHC, $n=7$, $\left.\mathrm{AUC}_{\text {median }}=5738\right)$ and $\mathrm{N}$-benzylamides $\left(\mathrm{BA}, n=2, \mathrm{AUC}_{\text {median }}=5928\right)$ exhibited the most potent effects, as depicted in Figure 2.

\subsection{Substitution Pattern Analysis of Aromatic Rings A and B}

To investigate the influence of the number and type of substituents on effectiveness, all data were analyzed for substitution patterns at the aromatic rings $\mathrm{A}$ and $\mathrm{B}$ (Figure $3 \mathrm{~A}$ ), independent of the base structure having a bicyclic system $(2-5,15,16)$ or not $(1,6-14,17,18)$, or being glycosylated (1-3) or not (4-18) (Table 1).

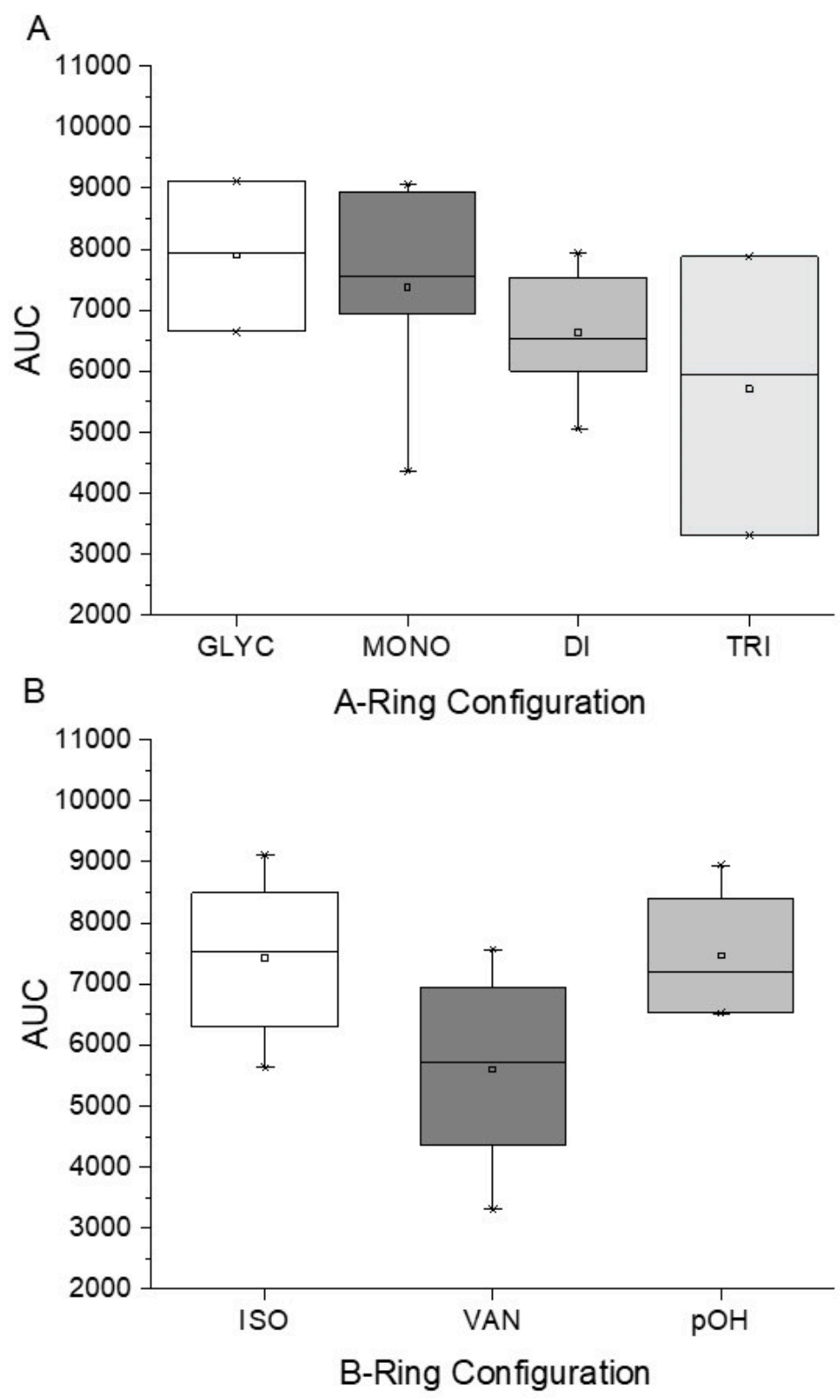

Figure 3. Clustering of compounds 1-18 according to structural similarity of (A) configuration on the A-ring, with glycoslated $(n=3 ; 1-3)$, monohydroxylated $(n=2 ; 12$ and 13), dihydroxylated $(n=8 ; 5$, 9-11, 14, 16, and 17), and trihydroxylated $(n=8 ; 1-4,6-8,15)$ and (B) configuration on the B-ring, with isovanilloyl $(n=9 ; 1-4,6,11,15$, and 16), vanilloyl ( $n=6 ; 7,10,12-14$, and 17), and p-hydroxy benzyl $\left(n=4 ; 5,8,9\right.$, and 18) moiety. Depicted are box-plots (min, $\mathrm{Q}_{0.25}$, median, $\mathrm{Q}_{0.75}$, max) of the respective group AUCs. 
Figure $3 \mathrm{~A}$ shows that for an IL-8 reducing effect, a trihydroxylated A-ring is preferable $\left(A U C_{\text {median }}=5524\right)$, as opposed to any other substitution pattern $\left(\mathrm{AUC}_{\text {median }}\right.$ between 6506 and 7769). Concerning the B-ring functional groups, our data suggest the vanilloyl group to be the most active for an anti-inflammatory effect (Figure 3B), with an $A U C_{\text {median }}=5464$ for the vanilloyl group compared to $\mathrm{AUC}_{\text {median }}=7290$ for the isovanilloyl group and $\mathrm{AUC}_{\text {median }}=7385$ for the $\mathrm{p}$-hydroxy benzyl moiety.

\subsection{Single Substance Matched}

\section{Matched Pair Analysis (MPA)}

Figure S1 shows the induction of IL-8 release by $p g$ LPS compared to the control as well as the anti-inflammatory effect of $1 \mu \mathrm{M}$ dexamethasone as a positive control. To compare the inhibitory effects of the compounds, all data are presented in comparison to the $p g$ LPS treatment (T/LPS, \%). As the groups depicted in Figure 2 showed diverse anti-inflammatory activities, we concentrated on the group closest related to $1(\mathbf{2}-\mathbf{4}, \mathbf{6}, \mathbf{7})$, subjecting single substances to a matched pair analysis (MPA), with only one structural difference between two compounds, by comparing mean AUCs (Table 1). Figure 4 shows the IL-8 release data for substances 1-4, 6, and $\mathbf{7}$ in direct comparison. While compounds $\mathbf{1}$, 3 , and 7 already exhibit an anti-inflammatory effect at the lowest tested concentration, compounds 4 and 6 show a concentration dependent inhibition of $p g$ LPS-induced IL-8 release. Furthermore, the inhibition of $p g$ LPS-induced IL- 8 release by $5 \mu \mathrm{M}$ compound 7 to $42.1 \pm 9.58 \%$ is comparable to the effect of the positive control, $1 \mu \mathrm{M}$ dexamethasone, reducing IL-8 release in HGF- 1 cells to $37.9 \pm 10.1 \%$ (Figure S1). In addition to IL-8 release, qPCR experiments for IL-8 mRNA expression were performed for the selected substances $(2-4,6)$ at $1 \mu \mathrm{M}, 10 \mu \mathrm{M}$, and $100 \mu \mathrm{M}$ after $3 \mathrm{~h}$ of incubation to compare to release data (see supplement Figure S4), confirming the concentration dependent activity of compound 6. However, comparing the individual AUC values of all related compounds, $2^{\prime}, 4,4^{\prime}, 6^{\prime}$-tetrahydroxy 3-methoxydihydrochalcone (7) possessed the greatest anti-inflammatory activity (AUC $=3303 \pm 816$ ).

For individual structure comparison, we first analyzed the influence of glycosylation (Figure 4A-C) compared to aglyca hesperitin dihydrochalcon (6) and hesperitin (4) (Figure 4D,E), with the comparison of 1 and 6,2 and 4 , and 3 and 4 . In the first two pairwise comparisons, glycosylation did have a more deleterious effect on activity in the A,B-linker system $\left(\triangle A U C_{1 / 6}=1985\right)$, as compared to the bicyclic core structure $\left(\triangle \mathrm{AUC}_{2 / 4}=1371\right)$. The attachment of a different disaccharide was tolerated better, diminishing the here tested bioactivity by $\triangle \mathrm{AUC}_{3 / 4}=1092$. In direct comparison of the glycosylated compounds, we could confirm that hesperidin $(3, \mathrm{AUC}=6648$, Figure $4 \mathrm{C})$ possessed a higher anti-inflammatory activity than neohesperidin $(2, \mathrm{AUC}=9111$, Figure $4 \mathrm{~B})$, with a $\triangle \mathrm{AUC}_{2 / 3}$ of 2463 . The structural difference between these two compounds resides in the disaccharide moiety. Therefore, we hypothesize that the sugar moiety also affects the anti-inflammatory impact of the compounds on $p g$ LPS-induced IL-8 release by HGF- 1 cells. We could not find a correlation between the effect on $p g$ LPS-induced IL-8 release with molecular weight, polarity, surface polarity, or hydrogen bond acceptors/donors. As we were able to test neohesperidin (2) in comparison to neohesperidin dihydrochalcone (1), a missing link in this group would be the anti-inflammatory evaluation of a hesperidin dihydrochalcone in comparison to hesperidin (3), but we were not able to obtain that substance in the present study. Cleavage of the C-ring of hesperitin (4) to the dihydrochalcone (A-ring-linker-B-ring)-system (6, Figure 4D), instead of the A,C-bicyclic system with a solitary B-ring (Figure 4E), revealed a notable difference in the effect size of $\Delta \mathrm{AUC}_{4 / 6}=1795$ and hesperitin dihydrochalcon as a very potent compound. Furthermore, changing the substitution pattern at the B-ring from an isovanilloylic to a vanilloylic ring resulted in a $\Delta \mathrm{AUC}_{6 / 7}=2642$. Thus, $2^{\prime}, 4,4^{\prime}, 6^{\prime}$-tetrahydroxy 3-methoxydihydrochalcone (7), the non-glycosylated dihydrochalcon with a vanilloylic B-ring remained the most potent anti-inflammatory substance tested (Figure 4F). 

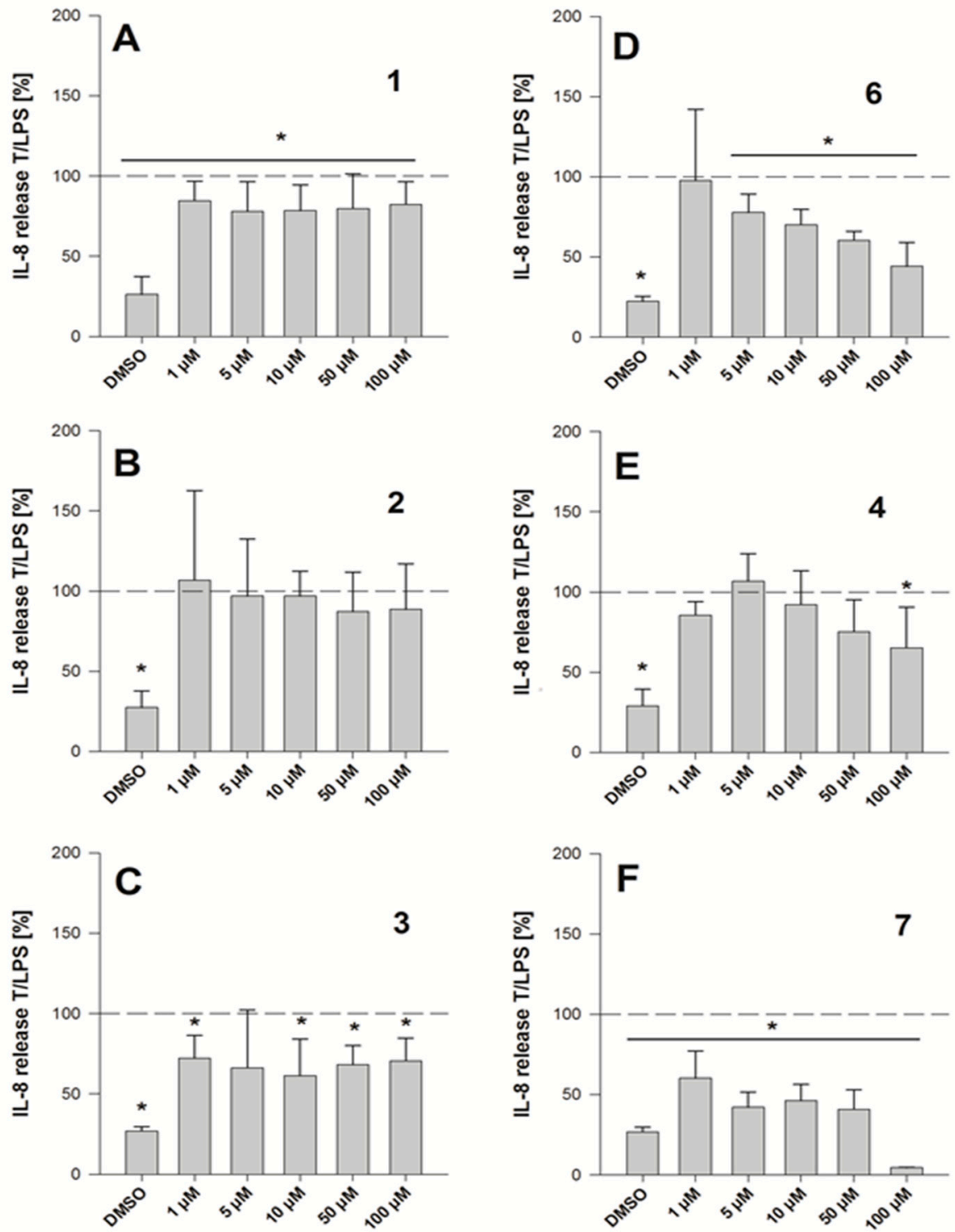

Figure 4. IL-8 release by HGF-1 cells expressed as test over $p g$ LPS control (\%) for compounds $\mathbf{1 - 4 , 6}$, and 7 (A-F) upon $6 \mathrm{~h}$ of co-incubation; data are depicted as average $\pm \mathrm{SD}, n=3-4$, technical replicates $=3$, *significant differences to $p g$ LPS control ( $p<0.05$, Student's $t$-test).

\section{Discussion}

Anti-inflammatory and antioxidant potential of polyphenols are often presented as collateral bioacitivies [5]. Here, our data suggest the more flexible A,B-linker system to be more beneficial for an anti-inflammatory activity than the bicyclic systems. On the other hand, in a QSAR analysis on antioxidant activities by Khlebnikov et al. [29], the more flexible A,B-linker systems were not superior to the bicyclic systems. A higher $\pi$-electron delocalization in the bicyclic system would of course be beneficial for radical scavenging effects. Small changes in the molecule structure might have an impact on pharmacodynamics and metabolic transformations which, in turn, might affect the antioxidant and anti-inflammatory activity. Such structure-specific activities of polyphenolic compounds regarding redox properties and anti-inflammatory activities have already been observed in our group for physiological metabolites of substance 18, namely resveratrol $[7,16,30]$. However, future studies are needed to elucidate this hypothesis. Another possibility would be a different mode of action of bicyclic and A,B-linker systems due to increased molecular flexibility. 
After our initial analysis of the A-ring substituents as shown in Figure 2, substances 7 (trihydroxylated), 10 (dihydroxylated), and $\mathbf{1 2}$ (monohydroxylated) were also subjected to individual matched pair analyses (MPA) to evaluate the impact of single changes in molecules that are otherwise identical. $\triangle \mathrm{AUC}_{7 / 10}$ (tri- vs dihydroxylated) and $\triangle \mathrm{AUC}_{10 / 12}$ (di- vs monohydroxylated) were 1749 and 1888, respectively, making the trihydroxylated A-ring the most potent substitution pattern, with a $\triangle \mathrm{AUC}_{7 / 12}$ of 3637 . The difference in bioactivity between tri- and di-hydroxylated compounds could also be established for bicyclic compounds 15 and 16, resulting in $\triangle \mathrm{AUC}_{15 / 16}$ of 1722 .

To obtain a detailed insight into the impact of B-ring substitution (vanilloyl/isovanilloyl/ p-OH-benzyl) on pgLPS-stimulated IL-8 release in HGF-1 cells, two direct comparisons were performed. Experiments with compounds $\mathbf{1 0}$ and $\mathbf{1 1}$ (both with dihydroxylated A-ring) revealed a lower $\triangle \mathrm{AUC}_{11 / 10}$ of 574 as opposed to compounds 6 and $7\left(\Delta \mathrm{AUC}_{6 / 7}=2642\right)$, both with trihydroxylated A-ring, indicating not only that the vanilloyl group was important for the bioactivity in both comparisons, but also that a combination of trihydroxylation of the A-ring with a vanilloyl group as the B-ring resulted in the highest bioactivity in the used in vitro system. As a last step, we increased the electronegativity of the A,B-ring linker by exchanging the keto group for an amide functional moiety. The result was a marked increase in effect size with a $\triangle A U C_{13 / 12}$ of 2577 , favoring the amidic function. Ideally, this hypothesis would have been proven by a comparison of $\mathbf{1 4}$ with the respective compound, which we unfortunately could not include in this study. The addition of a second hydroxyl group to the A-ring, which according to our earlier MPA analysis should have had positive effects, did on the contrary vastly diminish the effect $\left(\triangle \mathrm{AUC}_{13 / 14}=3195\right)$. Here, we hypothesize that for $\mathbf{1 4}$ the increased rigidity has a greater impact on the anti-inflammatory effect than the introduction of an additional hydroxyl group. This would be in accordance with the differences in activity we found for the much more rigid bicyclic structures $(\mathbf{2}-\mathbf{5}, \mathbf{1 5}, \mathbf{1 6})$ compared to compounds with two freely rotating aromatic rings (1, 6-13) with $\triangle \mathrm{AUC}_{(\text {median, bicyclic)/(median, A,B-linker) }}=1955$.

Compound 18, representing the compound class of stilbenes, with a well-documented anti-inflammatory activity [16], exhibited a much higher $\mathrm{AUC}_{\text {median }}$ (6362) compared to the majority of dihydrochalcones tested. Moreover, the shortening of the A,B-linker by one carbon atom was detrimental on the tested bioactivity in this study $\left(\triangle \mathrm{AUC}_{10 / 17}=1326\right)$, whereas the removal of the keto function in bicyclic compounds was of little difference with a $\Delta \mathrm{AUC}_{4 / 15}$ of 400 . For compound 18 (resveratrol), direct molecular interactions have been shown with cyclooxygenases, leukotriene hydrolases, and the transcription factor peroxysome proliferator activating receptor gamma (PPAR $\gamma$ ), all of which are involved in inflammation [31]. For the here tested dihydrochalcones, as far as we are aware, no such studies exist yet.

The chosen compounds share close structural similarities but show differences in their anti-inflammatory properties, which might be explained by different molecular mechanisms of action. For selected naturally occurring dihydrochalcones, a direct molecular interaction with cathepsins, enzymes involved in inflammation and metabolic disorders [32], has already been established by Burger et al. [33]. Future studies could, therefore, focus on this direct interaction. Another possibility would be the interaction with transcription factor(s), or a direct pathway inhibition at the TLR, for which dihydro-pyrrolo[2,3-d]pyrimidines have been recently demonstrated to be effective [34]. Concerning a possible interaction with transcription factor $\mathrm{Nf}-\mathrm{kB}$, it would be interesting to use the results presented here as a test set for already existing in silico screening systems for small molecule immune-modulators, as published by Tsai and colleagues for NF- $\mathrm{B}$ [35]. Here, the authors focused on the $p g$ LPS-induced release of IL-8 as a key cytokine of the immune response in HGF-1 cells. However, future studies may include the effect of the tested dihydrochalcones on the LPS-induced release of other cytokines such as IL-6 or MCP-1, which have been shown to be affected by various natural compounds [6,17]. Our results might also be useful in advancing efforts in the de novo design of anti-inflammatory drugs. It is possible that the anti-inflammatory activity of compounds with a chalcone or dihydrochalcone core, like the CXCL12 neutraligand, as published by Gasparik et al. [36], could also be enhanced by the introduction of the structural features identified in this study. 


\section{Materials and Methods}

\subsection{Chemicals}

Fetal bovine serum (FBS) was obtained from Invitrogen (Karlsruhe, Germany), pgLPS from InvivoGen (San Diego, CA, USA), the peqGOLD total RNA isolation kit and qPCR plates were purchased from Peqlab (Erlangen, Germany), and the high capacity cDNA reverse transcription kit and fast SYBR green mastermix for PCR experiments were from LifeTechnologies (Carlsbad, CA, USA). ELISA kits for IL-8 were obtained from Merck (Vienna, Austria). All other chemicals were from Sigma-Aldrich (Vienna, Austria).

\subsection{Compounds}

Compounds 1-5, 8, and 18 were obtained from Sigma-Aldrich (Munich, Germany). Compounds 13 and 14 were synthesized according to Ley et al. [37]. Compounds 7, 9, 12, and 17 were synthesized following the protocol published by Ley et al. [38]. Synthesis of compounds 6 (Figure A1), 10 (Figure A2), 11 (Figure A3), 15 (Figure A4), and 16 (Figure A5), as well as NMR data and purities of all synthesized compounds, are presented in Appendix A. Synthetic dihydrochalcones were tested alongside well-characterized natural compounds (2-5, 8, 9, and 18) [13,35,39-41] for a more comprehensive evaluation of the anti-inflammatory effect.

\subsection{Cell Culture}

The Human Gingival Fibroblasts (HGF-1) cell line was obtained from the American Type Culture Collection at passage 15. Cultures were split twice a week and for experiments, cells were only used up to passage 24. HGF-1 cells were cultivated in Dulbecco's Modified Eagle Medium (DMEM), supplemented with $10 \%$ fetal bovine serum, $100 \mathrm{U} / \mathrm{mL}$, penicillin, $0.1 \mathrm{mg} / \mathrm{mL}$ streptomycin, and $8 \mathrm{mM}$ glutamine in a humidified incubator with $5 \% \mathrm{CO}_{2}$ at $37{ }^{\circ} \mathrm{C}$. The specified medium was used in all experiments. For incubations, cells were seeded at a density of 5000 cells per well (96 well plates) in $200 \mu \mathrm{L}$ medium and allowed to attach and grow for three days.

Cells were then incubated in triplicates with Porphyromonas gingivalis LPS $(10 \mu \mathrm{g} / \mathrm{mL}, p g \mathrm{LPS})$ alone (pgLPS control) or co-incubated with five different concentrations of a test compound $(1-100 \mu \mathrm{M}, 100 \mu \mathrm{L}$ incubation medium) for $6 \mathrm{~h}$. Compounds were dissolved in DMSO to a concentration of $100 \mathrm{mM}$. Dilutions were then prepared for additional concentrations of $50 \mathrm{mM}, 10 \mathrm{mM}, 5 \mathrm{mM}$, and $1 \mathrm{mM}$ in $100 \%$ DMSO. Stocks were always prepared freshly on the day of incubation. The final solvent concentration was $0.1 \%$ DMSO in all experiments. The cell supernatant was then used to determine the IL- 8 release (see Section 4.5) and the cells were tested for their viability upon incubation (see Section 4.4).

\subsection{Cell Vitality}

Cell vitality was measured in 96 well plates after $6 \mathrm{~h}$ incubation using the MTT assay. After removal of cell supernatant, cells were incubated with $100 \mu \mathrm{L}$ of MTT reagent $(5 \mathrm{mg} / \mathrm{mL}$ in PBS, 1:6 dilution with serum-free medium) for 30-45 min. After removing the excessive MTT reagent, the blue formazan crystals formed within the viable cells were dissolved in $150 \mu \mathrm{L}$ DMSO, and absorption was measured at $570 \mathrm{~nm}$, with reference wavelength $650 \mathrm{~nm}$ with an Infinite M200 plate reader (Tecan, Austria). Viability was calculated as compared to cells incubated with a solvent-free medium.

\subsection{Measurement of IL-8 in Cell Culture Supernatants}

IL-8 levels in cell culture supernatants collected upon treatment (see Section 4.3) were measured by ELISA according to the manufacturer's protocol (Merck Millipore, Darmstadt, Germany) using an Infinite M200 plate reader (Tecan, Austria). 


\subsection{Analysis of IL-8 mRNA Expression in pgLPS-Stimulated HGF-1 Cells Incubated with Selected Dihydrochalcones}

For the detection of mRNA analysis, the $3 \mathrm{~h} p g$ LPS-stimulated and incubated HGF-1 cells were lyzed and mRNA was isolated using a commercial kit (Peqlab). Transcribed cDNA was used to perform the qPCR analysis with PPIA and GAPDH as reference genes (StepOnePlus, Applied Biosystems) as previously described [6]. Based on the $\mathrm{C}_{\mathrm{T}}$-values, the starting material $\mathrm{N}_{0}$ was calculated by LinRegPCR. $\mathrm{N}_{0}$-values of IL- 8 were normalized to the $\mathrm{N}_{0}$-values of the reference genes. The normalized $\mathrm{N}_{0}$-levels upon co-incubation with $p g$ LPS and the compound of interest were related to the normalized $\mathrm{N}_{0}$-levels of $p g$ LPS-stimulated cells $(100 \%)$.

\subsection{Statistical Analysis}

Data represent averages \pm SD and were analyzed using SigmaPlot version 13.0 (SystatSoftware, Erkrath, Germany). Prior to comparative testing, all sets were normality tested (Shapiro-Wilk). If normality was passed, a Student's $t$-test was performed $\left({ }^{*}, p<0.05\right)$ against $p g$ LPS control; if equal variance testing failed, a Wilcoxon-Mann-Whitney Rank Sum test was performed.

\section{Conclusions}

In conclusion, we determined for the here tested dihydrochalcone structure fragments, the most favorable combination is a trihydroxylated A-ring moiety with a vanilloylic B-ring moiety regarding a $p g$ LPS-induced IL-8 release reducing effect in human gingival fibroblasts (HGF-1 cells), as a well-established model of gingivitis. Additionally, the introduction of an electronegative atom in the A,B-linker chain may improve the reduction of a $p g$ LPS-induced IL-8 release as shown by the comparison of compounds $\mathbf{1 2}$ and $\mathbf{1 3}$. We, therefore, propose substances $\mathbf{7}$ and $\mathbf{1 3}$ to be used as lead structures in future assays on the anti-inflammatory activity of dihydrochalcones in oral inflammation.

Supplementary Materials: The analysis of IL-8 release and IL-8 mRNA expression are available online. Figure S1: Results for incubations with compounds 1-6 at $1 \mu \mathrm{M}, 5 \mu \mathrm{M}, 10 \mu \mathrm{M}, 50 \mu \mathrm{M}$, and $100 \mu \mathrm{M}$ in co-incubation with $p g$ LPS $(10 \mu \mathrm{g} / \mathrm{mL})$ in HGF-1 cells after $6 \mathrm{~h}$, Figure S2: Results for incubations with compounds 7-12 at $1 \mu \mathrm{M}, 5 \mu \mathrm{M}$, $10 \mu \mathrm{M}, 50 \mu \mathrm{M}$, and $100 \mu \mathrm{M}$ in co-incubation with $p g \mathrm{LPS}(10 \mu \mathrm{g} / \mathrm{mL})$ in HGF-1 cells after 6 h, Figure S3: Results for incubations with compounds 13-18 at $1 \mu \mathrm{M}, 5 \mu \mathrm{M}, 10 \mu \mathrm{M}, 50 \mu \mathrm{M}$, and $100 \mu \mathrm{M}$ in co-incubation with $p g \mathrm{LPS}$ $(10 \mu \mathrm{g} / \mathrm{mL})$ in HGF-1 cells after $6 \mathrm{~h}$, Figure S4: Results for mRNA expression upon incubation with compounds 2-4 and 6 at $1 \mu \mathrm{M}, 10 \mu \mathrm{M}$, and $100 \mu \mathrm{M}$ in co-incubation with $p g \mathrm{LPS}(10 \mu \mathrm{g} / \mathrm{mL})$ in HGF-1 cells after $3 \mathrm{~h}$.

Author Contributions: The authors contributed to the manuscript as follows: Conceptualization, J.P.L. and V.S.; methodology, J.W. and J.H.; validation, K.S., S.P., J.H., and J.W.; formal analysis, K.S., S.P., J.W., and J.H.; investigation, K.S., J.W., and S.P.; resources, V.S. and J.P.L.; data curation, K.S., S.P., J.W., and J.H.; writing-original draft preparation, K.S.; writing-review and editing, J.W., V.S., J.H., and J.P.L; visualization, K.S., S.P., and J.H.; supervision, V.S. and J.P.L.; project administration, V.S. and J.P.L.; funding acquisition, V.S. and J.P.L. All authors have read and agreed to the final version of the manuscript.

Funding: This research was financially supported by Symrise AG, Holzminden/Germany, and by the Austrian Federal Ministry of Economy, Family, and Youth and the Austrian National Foundation for Research, Technology, and Development. The APC was funded by the University of Vienna.

Acknowledgments: The authors would like to thank Katrin Geißler for the helpful and critical discussions. Open Access Funding is provided by the University of Vienna.

Conflicts of Interest: The authors Joachim Hans and Jakob P. Ley are employed by Symrise AG, Holzminden, Germany.

\section{Appendix A. Preparation and Structure Elucidation of Compounds 6, 10, 11, 15, and 16}

\section{Appendix A.1. Compound 6}

Compound 6 was prepared by dissolving compound 1 (Neohesperidin dihydrochalcone) in $\mathrm{MeOH} / 2 \mathrm{M} \mathrm{H}_{2} \mathrm{SO}_{4}(1: 1, v / v)$ and refluxing the mixture for $6 \mathrm{~h}$ (Figure A1). The reaction mixture was neutralized with $2 \mathrm{M} \mathrm{NaOH}$ for precipitation. After filtration, the precipitate was washed with water 
and dried at $40{ }^{\circ} \mathrm{C}$ under high vacuum. Compound 6 was obtained as a colorless solid with a yield of $77 \%$.

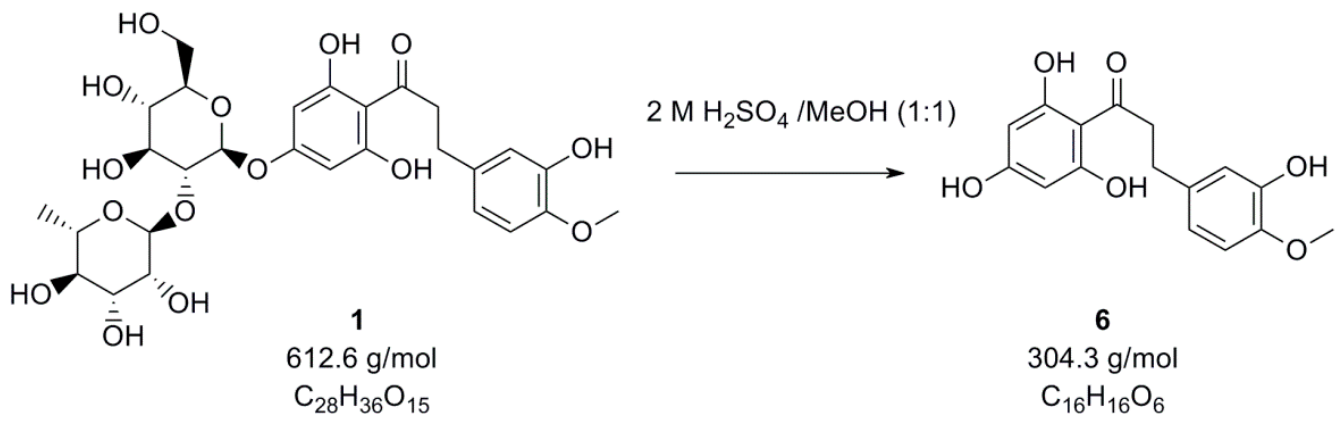

Figure A1. Preparation of compound 6.

Identity and purity was assessed by NMR: ${ }^{1} \mathrm{H}-\mathrm{NMR}(400 \mathrm{MHz}, \mathrm{DMSO}-\mathrm{d} 6): \delta 12.25$ (s, $\left.2 \mathrm{H}\right), 10.36$ $(\mathrm{s}, 1 \mathrm{H}), 8.79(\mathrm{~s}, 1 \mathrm{H}), 6.80(\mathrm{~d}, J=8.2 \mathrm{~Hz}, 1 \mathrm{H}), 6.66(\mathrm{~d}, J=2.1 \mathrm{~Hz}, 1 \mathrm{H}), 6.59(\mathrm{dd}, J=8.2,2.2 \mathrm{~Hz}, 1 \mathrm{H}), 5.81$ $(\mathrm{s}, 2 \mathrm{H}), 3.72(\mathrm{~s}, 3 \mathrm{H}), 3.22(\mathrm{dd}, J=8.5,6.9 \mathrm{~Hz}, 2 \mathrm{H}), 2.74(\mathrm{dd}, J=8.5,6.9 \mathrm{~Hz}, 2 \mathrm{H}) .{ }^{13} \mathrm{C} \mathrm{NMR}(100 \mathrm{MHz}$, DMSO-d6): $\delta$ 203.97, 164.51, 164.12 (2C), 146.19, 145.70, 134.13, 118.59, 115.61, 112.24, 103.60, 94.54 (2C), $55.59,45.11,29.42$; melting point (mp, uncorrected): $144-147^{\circ} \mathrm{C}$ under decomposition.

\section{Appendix A.2. Compound $\mathbf{1 0}$}

Compound 10 was synthesized using compounds $\mathbf{A}$ and $\mathbf{B}$. The synthesis of compounds $\mathbf{A}$ and $\mathbf{B}$ and compound $\mathbf{1 0}$ are shown in Figure A2.

Synthesis of compound A: One equivalent (eq) 4-hydroxy-3-methoxy-benzaldehyde and 2.2 eq benzylbromide were dissolved in ethanol containing 2 eq potassium hydroxide and refluxed $(\mathrm{RF})$ for $8 \mathrm{~h}$. After cooling the mixture to room temperature and evaporating to dryness, the residue was dissolved in ethyl acetate and washed three times with $\mathrm{H}_{2} \mathrm{O}$. The organic phase was then dried with anhydrous sodium sulfate and evaporated to dryness. The crude product $(74.9 \%$ 4-benzyloxy-3-methoxybenzaldehyde as determined by GC) was recrystallized from ethanol, yielding $81.4 \%$ of 4-benzyloxy-3-methoxybenzaldehyde with a purity of $100 \%$ (GC).

Synthesis of compound B: One eq $2^{\prime}, 4^{\prime}$-dihydroxyacetophenone was dissolved in acetone and 2.2 eq of potassium carbonate were added under stirring, followed by the addition of 1.1 eq benzyl bromide. The mixture was stirred for $20 \mathrm{~h}$ at room temperature, filtered using a Büchner funnel, and the separated salt residues were washed with acetone. The collected filtrate was then evaporated to dryness and taken up in ethyl acetate. The organic phase was washed with a sodium chloride solution $(10 \%, w / v)$, dried with anhydrous sodium sulfate, and evaporated to dryness. The resulting crude crystalline product was dissolved in hexane/acetone $(3: 1, v / v)$ under reflux. After cooling down, the resulting precipitate was isolated via filtration and after drying identified as $2^{\prime}$-hydroxy-4'-benzyloxy-acetophenone (99.9\% purity as determined by GC, yield 70.7\%).

Synthesis of compound 10: One eq A and one eq B were dissolved in ethanol. A total of $1.2 \mathrm{eq}$ potassium hydroxide solution $(15 \%, w / v)$ were added dropwise under constant cooling over 5 min. After stirring at $25^{\circ} \mathrm{C}$ overnight, the mixture was cooled down to $0-5{ }^{\circ} \mathrm{C}$ and stirred for another $1.5 \mathrm{~h}$. The mixture was then acidified with 2 eq glacial acetic acid and precipitated with $\mathrm{H}_{2} \mathrm{O}$ by stirring at $0-5{ }^{\circ} \mathrm{C}$ for $1 \mathrm{~h}$. The precipitate was filtered, washed 3 times with ethanol $(50 \%)$, and dried at $80{ }^{\circ} \mathrm{C}$. The dried precipitate was then dissolved in a mixture (1:1) of tetrahydrofuran and ethanolic potassium hydroxid solution $(10 \%, w / v)$ and refluxed for $18 \mathrm{~h}$. After cooling, the mixture was again acidified with glacial acetic acid and precipitated with $\mathrm{H}_{2} \mathrm{O}$ by stirring at $0-5{ }^{\circ} \mathrm{C}$ for $1 \mathrm{~h}$. The crude precipitate was then recrystallized from acetone. The refined product was then dissolved in ethyl acetate/ethanol $(2: 1, v / v)$, hydrogenated using $\mathrm{Pd} / \mathrm{C} 5 \%$ (for approximately $6 \mathrm{~h}$ ). After the removal of the catalyst 
via filtration over $\mathrm{SiO}_{2}$, the solvent was evaporated, and the crude product was recrystallized from hexane/ethyl acetate.<smiles>COc1cc(C=O)ccc1O</smiles><smiles>CCOC(=O)OCc1ccccc1COc1ccc(C=O)cc1OC</smiles><smiles>CC(=O)c1ccc(O)cc1O</smiles><smiles>BrCc1ccccc1</smiles><smiles>CC(=O)O[Mg]</smiles>

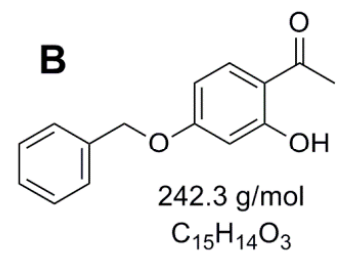

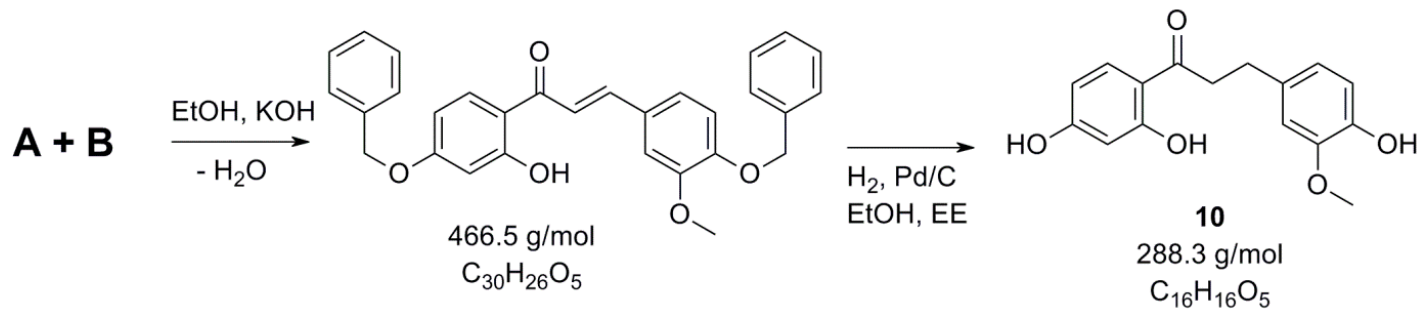

Figure A2. Synthesis of compounds A, B, and $\mathbf{1 0 .}$

The synthesis of compound 10 resulted in a yield of $45.4 \%$, with a purity of $97.7 \%$ as determined by NMR. ${ }^{1} \mathrm{H}-\mathrm{NMR}(400 \mathrm{MHz}$, DMSO-d6): $\delta$ ppm 12.65 (s, OH), $7.81(\mathrm{~d}, J=8.9 \mathrm{~Hz}, 1 \mathrm{H}), 6.83(\mathrm{~d}, J=1.5$ $\mathrm{Hz}, 1 \mathrm{H}), 6.66(\mathrm{~d}, J=7.9 \mathrm{~Hz}, 1 \mathrm{H}), 6.63(\mathrm{dd}, J=8.0,1.7 \mathrm{~Hz}, 1 \mathrm{H}), 6.36(\mathrm{dd}, J=8.8,2.3 \mathrm{~Hz}, 1 \mathrm{H}), 6.25(\mathrm{~d}$, $J=2.3 \mathrm{~Hz}, 1 \mathrm{H}), 3.74(\mathrm{~s}, 3 \mathrm{H}), 3.65-3.46(\mathrm{~m}, \mathrm{OH}), 3,23(\mathrm{t}, J=7.6 \mathrm{~Hz}, 2 \mathrm{H}), 2.83(\mathrm{t}, J=7.6 \mathrm{~Hz}, 2 \mathrm{H}), 2.50$ (s, OH), $1.26(\mathrm{dd}, J=18.3,4.0 \mathrm{~Hz}, \mathrm{OH}), 0.9-0.82(\mathrm{~m}, \mathrm{OH}) .{ }^{13} \mathrm{C}$ NMR $(101 \mathrm{MHz}, \mathrm{DMSO}) \delta \mathrm{ppm} 203.83$, 164.67, 164.15, 147.28, 144.56, 132.95, 131.60, 120.32, 115.15, 112.55, 112.44, 108.05, 102.29, 55.44, 40.04, $39.83,39.62,39.41,39.20,38.99,38.79,30.86,29.49,21.97,13.87 ; \mathrm{mp}$ (uncorrected): $147-149{ }^{\circ} \mathrm{C}$.

\section{Appendix A.3. Compound $\mathbf{1 1}$}

One eq isovanillin and one eq $2^{\prime}, 4^{\prime}$-dihydroxyacetophenone were dissolved in isopropanol and 4 eq potassium hydroxide solution $(45 \%, w / v)$ were added continuously over 10 min (Figure A3). The reaction mixture was heated up to $80^{\circ} \mathrm{C}$ under stirring and refluxed for $8 \mathrm{~h}$. Half of the reaction volume was removed using a Claisen condenser and the remaining mixture was diluted with 4 volumes of $\mathrm{H}_{2} \mathrm{O}$ and acidified with 6 eq glacial acetic acid under stirring for precipitation. The product mixture ( $286.3 \mathrm{~g} / \mathrm{mol}, 47 \% / 53 \%$ as determined by NMR) was filtered, washed with $\mathrm{H}_{2} \mathrm{O}$, and dried at $70{ }^{\circ} \mathrm{C}$. The obtained product mixture was taken up in glacial acetic acid and reacted with 2 eq ammonium formiate and $\mathrm{Pd} / \mathrm{C} 5 \%$ under reflux conditions for $7 \mathrm{~h}$. After separation of the catalyst via filtration, the glacial acetic acid was evaporated, the residue was dissolved with ethyl acetate, washed twice with water, dried over $\mathrm{Na}_{2} \mathrm{SO}_{4}$, and the solvent was removed under vacuum. The crude product was then dissolved in isopropanol/ $\mathrm{H}_{2} \mathrm{O}(3: 7, v / v)$ and stirred overnight at room temperature. 
<smiles>COc1ccc(C=O)cc1O</smiles>

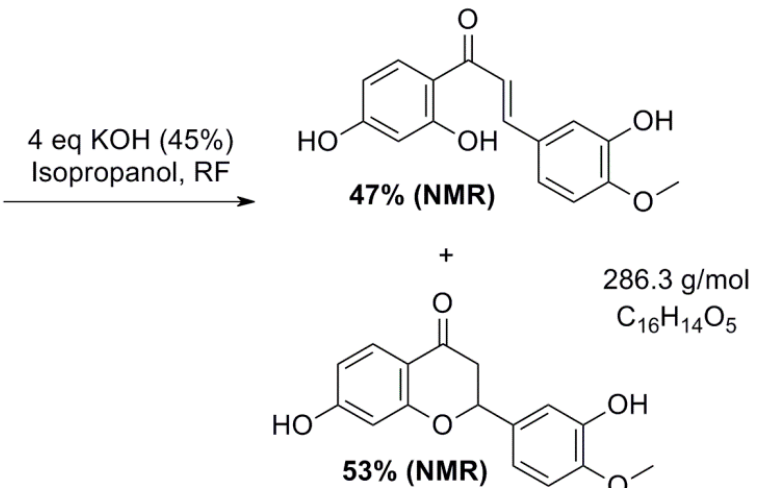<smiles>COc1ccc(CCC(=O)c2ccc(O)cc2O)cc1O</smiles>

Figure A3. Synthesis of compound 11.

The formed crystals were washed 3 times with $\mathrm{H}_{2} \mathrm{O}$ and dried at $70{ }^{\circ} \mathrm{C}$, resulting in compound 11 as a pearl-white solid (purity of $99.3 \%$, as determined by NMR). ${ }^{1} \mathrm{H}-\mathrm{NMR}\left(400 \mathrm{MHz}, \mathrm{DMSO}-d_{6}\right): \delta$ ppm $12.62(\mathrm{~s}, \mathrm{OH}), 7.79(\mathrm{~d}, J=8.9 \mathrm{~Hz}, 1 \mathrm{H}), 6.80(\mathrm{~d}, J=8.2 \mathrm{~Hz}, 1 \mathrm{H}), 6.68(\mathrm{~d}, J=2.1 \mathrm{~Hz}, 1 \mathrm{H}), 6.62(\mathrm{dd}$, $J=8.2,2.1 \mathrm{~Hz}, 1 \mathrm{H}), 6.36(\mathrm{dd}, J=8.8,2.4 \mathrm{~Hz}, 1 \mathrm{H}), 6.25(\mathrm{~d}, J=2.3 \mathrm{~Hz}, 1 \mathrm{H}), 3.72(\mathrm{~s}, 3 \mathrm{H}), 3,20(\mathrm{t}, J=7.5 \mathrm{~Hz}$, 2H), $2.79(\mathrm{t}, J=7.5 \mathrm{~Hz}, 2 \mathrm{H}) .{ }^{13} \mathrm{C}$ NMR (101 MHz, DMSO) $\delta \mathrm{ppm}$ 203.61, 164.67, 164.12, 146.19, 145.80, $133.50,132.87,118.64,115.69,112.42,112.20,108.06,102.30,55.60,40.03,39.82,39.61,39.41,39.20,39.05$, 38.99, 38.78, 29.04; $\mathrm{mp}$ (uncorrected): $118^{\circ} \mathrm{C}$ under decomposition.

\section{Appendix A.4. Compound 15}

According to a known procedure [42], 1.0 eq hesperetin was taken up in 12.4 eq pyridine, and 4.4 eq of bis(trimethylsilyl)amine were added (Figure A4). Subsequently, 4.7 eq of trimethylsilyl chloride were added dropwise, and the mixture was stirred for another half hour. Pyridin was evaporated and 94 eq toluol were added to the remaining reaction volume. The mixture was filtered and evaporated. The remaining oily residue was taken up in 31 eq tetrahydrofuran. Subsequently, 0.5 eq lithium borohydride was carefully added, and after stirring for $1 \mathrm{~h}, 1 \mathrm{eq}$ sodium borohydride cyanide was added, as well as $0.5 \mathrm{mg}$ methyl orange as an indicator. Hydrochloric acid (1 M) was added dropwise until a stable color change was detected. THF was evaporated and the remaining mixture was extracted three times with ethyl acetate. The organic phase was then washed with hydrochloric acid $(1 \mathrm{M}), \mathrm{H}_{2} \mathrm{O}$, and saturated sodium chloride solution, and evaporated to dryness.

The product was purified ( $>99 \%$ as determined by NMR) by column chromatography with a solvent mixture of ethyl acetate/pentane (1:1). ${ }^{1} \mathrm{H}-\mathrm{NMR}\left(400 \mathrm{MHz}, \mathrm{DMSO}-d_{6}\right)$ : $\delta \mathrm{ppm} 9.16(\mathrm{~s}, \mathrm{OH}), 8.97$ $(\mathrm{s}, 1 \mathrm{H}), 8.92(\mathrm{~s}, 1 \mathrm{H}), 6.89(\mathrm{~d}, J=8.3 \mathrm{~Hz}, 1 \mathrm{H}), 6.81(\mathrm{~d}, J=1.9 \mathrm{~Hz}, 1 \mathrm{H}), 6.76(\mathrm{dd}, J=8.3,1.9 \mathrm{~Hz}, 1 \mathrm{H}), 5.89$ $(\mathrm{d}, J=2.3 \mathrm{~Hz}, 1 \mathrm{H}), 5.70(\mathrm{~d}, J=2.3 \mathrm{~Hz}, 1 \mathrm{H}), 4.81(\mathrm{dd}, J=9.7,1.6 \mathrm{~Hz}, 1 \mathrm{H}), 3.75(\mathrm{~s}, 3 \mathrm{H}), 2.49(\mathrm{dd}, J=9.4$, $4.7 \mathrm{~Hz}, 2 \mathrm{H}), 2.06-1.96$ (m, 1H), 1.89-1.74 (m, 1H). ${ }^{13} \mathrm{C}$ NMR (101 MHz, DMSO) $\delta$ ppm 156.19, 156.02, 155.94, 146.97, 146.23, 134.36, 116.75, 113.34, 111.90, 100.12, 94.86, 94.16, 76.19, 55.55, 40.02, 39.81, 39.60, $39.39,39.18,38.97,38.77,28.93,18.77 ; \mathrm{mp}$ (uncorrected): $164-166^{\circ} \mathrm{C}$. 
<smiles>COc1ccc(C2CC(=O)c3c(O)cc(O)cc3O2)cc1O</smiles>

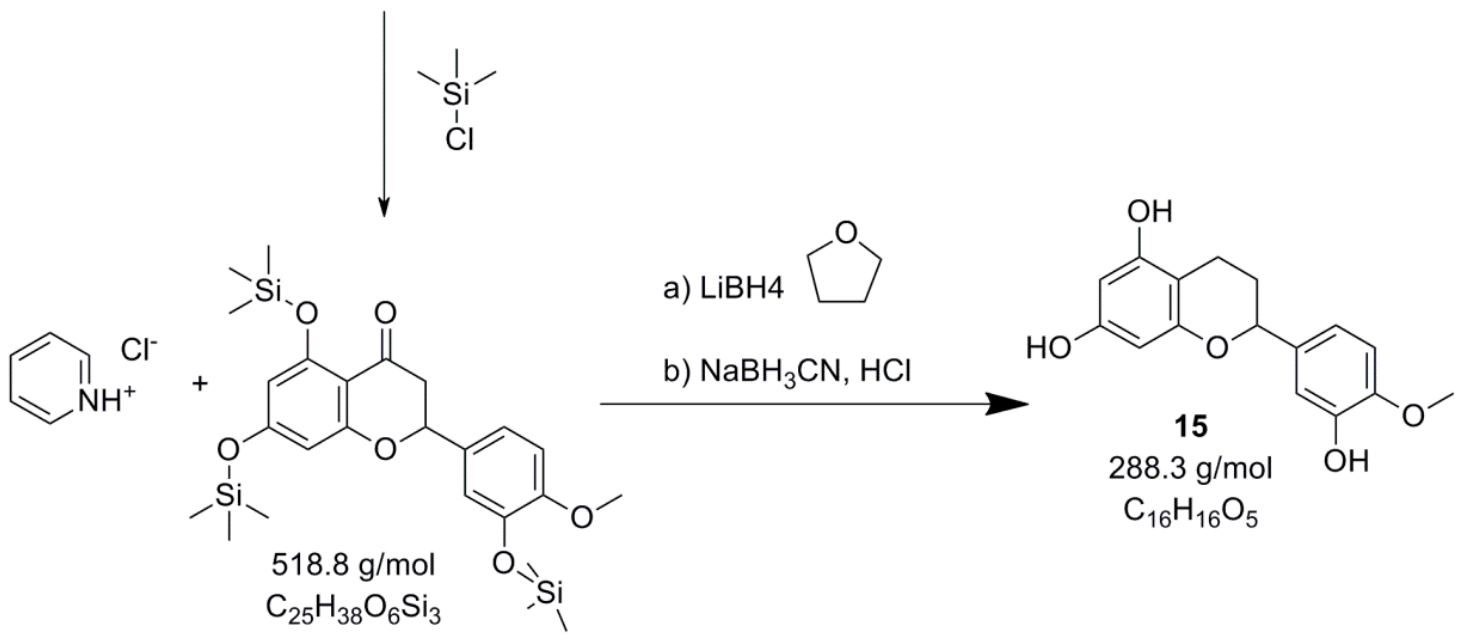

Figure A4. Preparation of compound 15.

\section{Appendix A.5. Compound $\mathbf{1 6}$}

To synthesize compound 16, compounds 16A and 16B needed to be synthesized first (Figure A5). Synthesis of compound 16A: One eq 3-hydroxy-4-methoxybenzaldehyde was dissolved in acetone and 1.2 eq potassium carbonate were added under reflux, followed by the dropwise addition of 1 eq benzyl bromide over $30 \mathrm{~min}$. The mixture was refluxed for $14 \mathrm{~h}$, diluted with $\mathrm{H}_{2} \mathrm{O}$, and extracted with ethyl acetate. The organic phase was then washed with $\mathrm{H}_{2} \mathrm{O}$ and sodium chloride solution, dried with sodium sulfate and evaporated to dryness to yield 3-benzyloxy-4-methoxybenzaldehyde ( $97.1 \%$ purity as determined by GC). The aldehyde reacted with methylmagnesium bromide in diethyl ether/tetrahydrofuran. After quenching the reaction with ice and sulfuric acid $(10 \%, \mathrm{pH}<2)$ under nitrogen gas, the mixture was diluted with ethyl acetate. The organic phase was washed with $\mathrm{H}_{2} \mathrm{O}$, sodium carbonate solution, and sodium chloride solution, and evaporated to dryness, yielding 1-(3-benzyloxy-4-methoxyphenyl)ethanol (purity $84.6 \%$ as determined by GC). The resulting alcohol was oxidized in dichloromethane using manganese (IV) oxide at room temperature for $144 \mathrm{~h}$. After removing manganese (IV) oxide by filtration, the filtrate was run through a $\mathrm{SiO}_{2}$-filled column and evaporated to dryness. The product was recrystallized from hexane/acetone $(4: 1, v / v)$ and yielded 1-(3-benzyloxy-4-methoxyphenyl)ethanone (16A, purity $99.3 \%$ as determined by GC). The overall yield was $34.4 \%$ over three steps.

Synthesis of compound 16B: One eq $2^{\prime}, 4^{\prime}$-dihydroxybenzaldehyde was dissolved in acetone and 2.4 eq potassium carbonate were added under reflux, followed by the dropwise addition of 2.1 eq benzyl bromide over $30 \mathrm{~min}$. The mixture was refluxed for $10 \mathrm{~h}$ and cooled down to room temperature. After removal of the precipitated salts by filtration, the filtrate was evaporated to dryness. The crude product was then recrystallized from acetone ( $97.8 \%$ purity as determined by GC). 


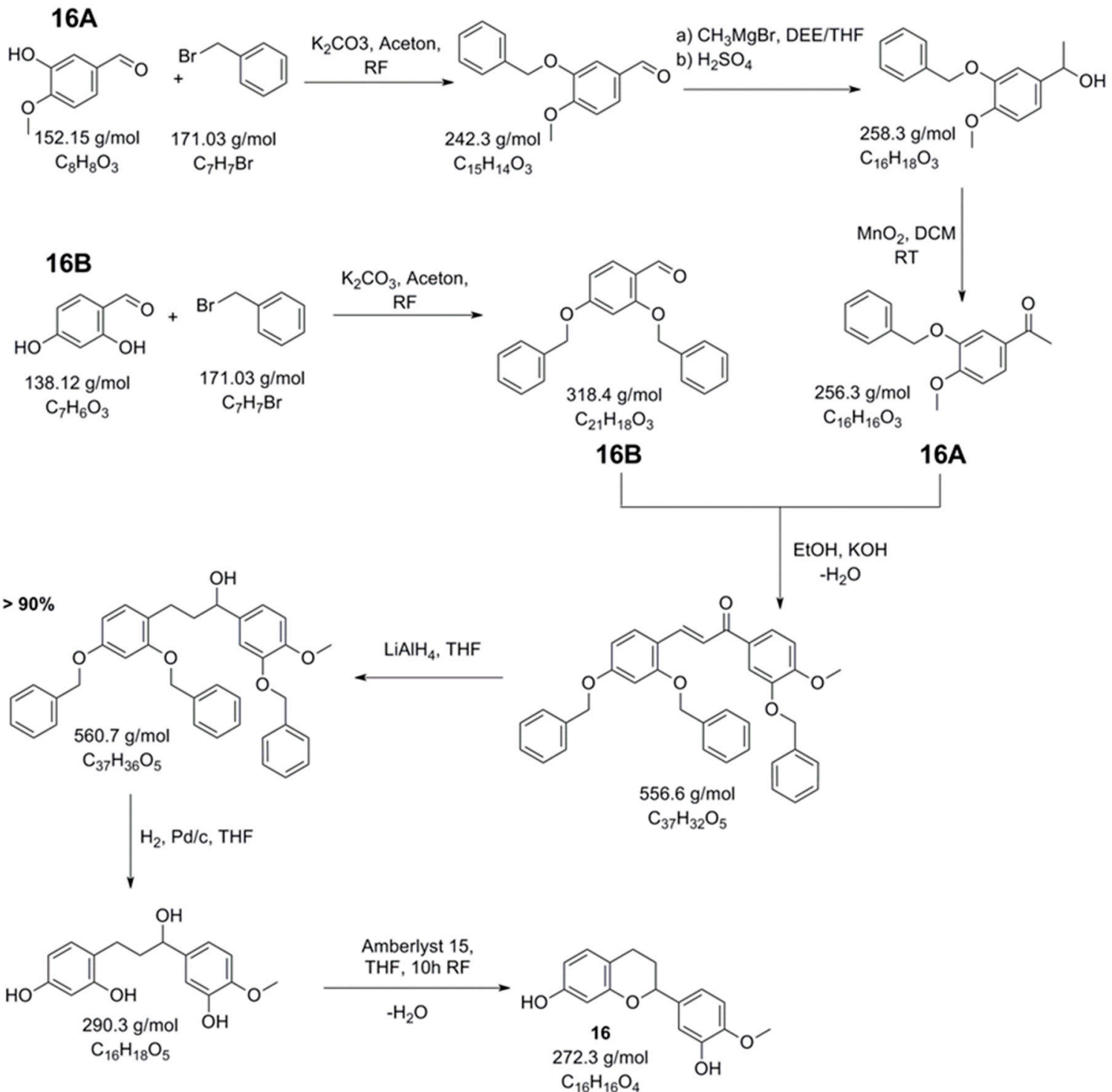

Figure A5. Synthesis of compounds 16A, 16B, and 16.

Synthesis of compound 16: One eq 16A and one eq 16B were dissolved in ethanol and 0.5 eq potassium hydroxide was added at room temperature. During refluxing for $12 \mathrm{~h}$, precipitation could already be observed. Ethanol/ $\mathrm{H}_{2} \mathrm{O}(1: 1, v / v)$ was added and the mixture was vacuum filtered. The precipitate was washed 4 times with Ethanol/ $\mathrm{H}_{2} \mathrm{O}(1: 1, v / v)$ and dried at $70{ }^{\circ} \mathrm{C}$. One eq of precipitate was then dissolved in anhydrous tetrahydrofuran, cooled to $10{ }^{\circ} \mathrm{C}$ under inert gas, and $0.5 \mathrm{eq}$ of lithium aluminium hydride dissolved in tetrahydrofuran was added dropwise, while keeping the reaction temperature under $20^{\circ} \mathrm{C}$. After stirring for $3 \mathrm{~h}$ at room temperature, the reaction mixture was then again cooled to $0{ }^{\circ} \mathrm{C}$, and the reaction was quenched by adding $\mathrm{H}_{2} \mathrm{O}$ and sodium hydroxide solution $(15 \%, v / w)$. After the addition of sodium sulfate, the mixture was stirred for another half hour. The reaction mixture was filtered and the filtrate was evaporated to dryness.

The intermediate compound was hydrogenated in tetrahydrofuran with $\mathrm{Pd} / \mathrm{C} 5 \%$ as a catalyst for $12 \mathrm{~h}$ and evaporated to dryness after filtration. For cyclization, the resulting product was refluxed for $10 \mathrm{~h}$ in tetrahydrofuran with Amberlyst 15, filtered, and evaporated to dryness. After Flash-LC purification (Silica 60, solvent hexane/ethyl acetate 3:2, v/v) the final product was recrystallized from hexane/acetone $(2: 1, v / v)$, and yielded $33.0 \%$ of compound 16 over four steps as an off-white solid (purity $>95 \%$ as determined by NMR). ${ }^{1} \mathrm{H}-\mathrm{NMR}\left(400 \mathrm{MHz}, \mathrm{DMSO}-d_{6}\right): \delta \mathrm{ppm} 9.07(\mathrm{~s}, \mathrm{OH}), 6.89(\mathrm{~d}$, $J=8.3 \mathrm{~Hz}, 1 \mathrm{H}), 6.84(\mathrm{~d}, J=8.3 \mathrm{~Hz}, 1 \mathrm{H}) 6.82(\mathrm{~d}, J=2.1 \mathrm{~Hz}, 1 \mathrm{H}), 6.77(\mathrm{dd}, J=8.3,2.0 \mathrm{~Hz}, 1 \mathrm{H}), 6.28$ 
$(\mathrm{dd}, J=8.2,2.4 \mathrm{~Hz}, 1 \mathrm{H}), 6.19(\mathrm{~d}, J=2.4 \mathrm{~Hz}, 1 \mathrm{H}), 4.89(\mathrm{dd}, J=9.8,2.1 \mathrm{~Hz}, 1 \mathrm{H}), 3.76(\mathrm{~s}, 3 \mathrm{H}), 2.78(\mathrm{ddd}$, $J=16.3,11.0,5.8 \mathrm{~Hz}, 1 \mathrm{H}), 2.57(\mathrm{dt}, J=15.9,4.4 \mathrm{~Hz}, 1 \mathrm{H}), 2.04(\mathrm{ddd}, J=13.5,5.2,2.7 \mathrm{~Hz}, 1 \mathrm{H}), 1.95-1.80$ (m, 1H). ${ }^{13} \mathrm{C}$ NMR (101 MHz, DMSO) $\delta$ ppm 156.35, 155.26, 147.02, 146.27, 134.22, 129.72, 116.74, 113.32, $112.09,111.92,107.83,102.63,76.48,55.56,40.03,39.82,39.61,39.40,39.20,38.99,38.78,29.32,23.59 ; \mathrm{mp}$ (uncorrected): $163-165^{\circ} \mathrm{C}$.

\section{References}

1. Petersen, P.E. The World Oral Health Report 2003: Continuous Improvement of Oral Health in the 21st century - the Approach of the WHO Global Oral Health Programme. Community Dent. Oral Epidemiol 2003, 31 Suppl. 1, 3-23. [CrossRef]

2. Dentino, A.; Lee, S.; Mailhot, J.; Hefti, A.F. Principles of periodontology. Periodontol 2000 2013, 61, 16 -53. [CrossRef] [PubMed]

3. den Boer, J.C.L.; van Dijk, W.; Horn, V.; Hescot, P.; Bruers, J.J.M. Collecting standardised oral health data via mobile application: A proof of concept study in the Netherlands. PLoS ONE 2018, 13, e0191385. [CrossRef] [PubMed]

4. Walker, J.; Imboeck, J.M.; Walker, J.M.; Maitra, A.; Haririan, H.; Rausch-Fan, X.; Dodds, M.; Inui, T.; Somoza, V. Magnolia officinalis L. Fortified Gum Improves Resistance of Oral Epithelial Cells Against Inflammation. Am. J. Chin. Med. 2016, 44, 1167-1185. [CrossRef] [PubMed]

5. Zhang, L.; Ravipati, A.S.; Koyyalamudi, S.R.; Jeong, S.C.; Reddy, N.; Smith, P.T.; Bartlett, J.; Shanmugam, K.; Munch, G.; Wu, M.J. Antioxidant and anti-inflammatory activities of selected medicinal plants containing phenolic and flavonoid compounds. J. Agric. Food Chem. 2011, 59, 12361-12367. [CrossRef] [PubMed]

6. Josino Soares, D.; Walker, J.; Pignitter, M.; Walker, J.M.; Imboeck, J.M.; Ehrnhoefer-Ressler, M.M.; Montenegro Brasil, I.; Somoza, V. Pitanga (Eugenia uniflora L.) fruit juice and two major constituents thereof exhibit anti-inflammatory properties in human gingival and oral gum epithelial cells. Food Funct. 2014, 5, 2981-2988. [CrossRef] [PubMed]

7. Schueller, K.; Pignitter, M.; Somoza, V. Sulfated and Glucuronated trans-Resveratrol Metabolites Regulate Chemokines and Sirtuin-1 Expression in U-937 Macrophages. J. Agric. Food Chem. 2015, 63, 6535-6545. [CrossRef] [PubMed]

8. Shi, Q.; Song, X.; Fu, J.; Su, C.; Xia, X.; Song, E.; Song, Y. Artificial sweetener neohesperidin dihydrochalcone showed antioxidative, anti-inflammatory and anti-apoptosis effects against paraquat-induced liver injury in mice. Int. Immunopharmacol. 2015, 29, 722-729. [CrossRef]

9. Hu, L.; Li, L.; Xu, D.; Xia, X.; Pi, R.; Xu, D.; Wang, W.; Du, H.; Song, E.; Song, Y. Protective effects of neohesperidin dihydrochalcone against carbon tetrachloride-induced oxidative damage in vivo and in vitro. Chem. Biol. Interact. 2014, 213, 51-59. [CrossRef]

10. Huang, Y.C.; Guh, J.H.; Cheng, Z.J.; Chang, Y.L.; Hwang, T.L.; Lin, C.N.; Teng, C.M. Inhibitory effect of DCDC on lipopolysaccharide-induced nitric oxide synthesis in RAW 264.7 cells. Life Sci. 2001, 68, 2435-2447. [CrossRef]

11. Al-Rikabi, R.; Al-Shmgani, H.; Dewir, Y.H.; El-Hendawy, S. In vivo and in vitro Evaluation of the Protective Effects of Hesperidin in Lipopolysaccharide-Induced Inflammation and Cytotoxicity of Cell. Molecules 2020, 25, 478. [CrossRef] [PubMed]

12. Jung, M.; Triebel, S.; Anke, T.; Richling, E.; Erkel, G. Influence of apple polyphenols on inflammatory gene expression. Mol. Nutr. Food Res. 2009, 53, 1263-1280. [CrossRef]

13. Chang, W.T.; Huang, W.C.; Liou, C.J. Evaluation of the anti-inflammatory effects of phloretin and phlorizin in lipopolysaccharide-stimulated mouse macrophages. Food Chem. 2012, 134, 972-979. [CrossRef]

14. Darveau, R.P. Periodontitis: A polymicrobial disruption of host homeostasis. Nat. Rev. Microbiol. 2010, 8, 481-490. [CrossRef]

15. Campbell, L.M.; Maxwell, P.J.; Waugh, D.J. Rationale and Means to Target Pro-Inflammatory Interleukin-8 (CXCL8) Signaling in Cancer. Pharmaceuticals 2013, 6, 929-959. [CrossRef]

16. Walker, J.; Schueller, K.; Schaefer, L.M.; Pignitter, M.; Esefelder, L.; Somoza, V. Resveratrol and its metabolites inhibit pro-inflammatory effects of lipopolysaccharides in U-937 macrophages in plasma-representative concentrations. Food Funct. 2014, 5, 74-84. [CrossRef] 
17. Yiemwattana, I.; Kaomongkolgit, R. Alpha-mangostin suppresses IL-6 and IL-8 expression in P. gingivalis LPS-stimulated human gingival fibroblasts. Odontology 2015, 103, 348-355. [CrossRef]

18. McClanahan, S.F.; Bartizek, R.D. Effects of triclosan/copolymer dentifrice on dental plaque and gingivitis in a 3-month randomized controlled clinical trial: Influence of baseline gingivitis on observed efficacy. J. Clin. Dent. 2002, 13, 167-178.

19. Nayak, P.A.; Nayak, U.A.; Mythili, R. Effect of Manuka honey, chlorhexidine gluconate and xylitol on the clinical levels of dental plaque. Contemp Clin. Dent. 2010, 1, 214-217.

20. Maruyama, T.; Tomofuji, T.; Endo, Y.; Irie, K.; Azuma, T.; Ekuni, D.; Tamaki, N.; Yamamoto, T.; Morita, M. Supplementation of green tea catechins in dentifrices suppresses gingival oxidative stress and periodontal inflammation. Arch. Oral Biol. 2011, 56, 48-53. [CrossRef]

21. Muhammad, T.; Ikram, M.; Ullah, R.; Rehman, S.U.; Kim, M.O. Hesperetin, a Citrus Flavonoid, Attenuates LPS-Induced Neuroinflammation, Apoptosis and Memory Impairments by Modulating TLR4/NF-kappaB Signaling. Nutrients 2019, 11, 648. [CrossRef]

22. Jo, S.H.; Kim, M.E.; Cho, J.H.; Lee, Y.; Lee, J.; Park, Y.D.; Lee, J.S. Hesperetin inhibits neuroinflammation on microglia by suppressing inflammatory cytokines and MAPK pathways. Arch. Pharm Res. 2019, 42, 695-703. [CrossRef]

23. Lim, K.H.; Staudt, L.M. Toll-Like Receptor Signaling. Csh. Perspect Biol. 2013, 5, 1-4. [CrossRef]

24. Zarubin, T.; Han, J. Activation and signaling of the p38 MAP kinase pathway. Cell Res. 2005, 15, 11-18. [CrossRef]

25. Luo, X.; Yu, Z.; Deng, C.; Zhang, J.; Ren, G.; Sun, A.; Mani, S.; Wang, Z.; Dou, W. Baicalein ameliorates TNBS-induced colitis by suppressing TLR4/MyD88 signaling cascade and NLRP3 inflammasome activation in mice. Sci. Rep. 2017, 7, 16374. [CrossRef]

26. Mendonca, P.; Taka, E.; Bauer, D.; Reams, R.R.; Soliman, K.F.A. The attenuating effects of 1,2,3,4,6 penta-O-galloyl-beta-d-glucose on pro-inflammatory responses of LPS/IFNgamma-activated BV-2 microglial cells through NFkB and MAPK signaling pathways. J. Neuroimmunol. 2018, 324, 43-53. [CrossRef]

27. Tong, W.; Chen, X.; Song, X.; Chen, Y.; Jia, R.; Zou, Y.; Li, L.; Yin, L.; He, C.; Liang, X.; et al. Resveratrol inhibits LPS-induced inflammation through suppressing the signaling cascades of TLR4-NF-kappaB/MAPKs/IRF3. Exp. Ther. Med. 2020, 19, 1824-1834.

28. Ehrnhofer-Ressler, M.M.; Fricke, K.; Pignitter, M.; Walker, J.M.; Walker, J.; Rychlik, M.; Somoza, V. Identification of 1,8-cineole, borneol, camphor, and thujone as anti-inflammatory compounds in a Salvia officinalis L. infusion using human gingival fibroblasts. J. Agric. Food Chem. 2013, 61, 3451-3459. [CrossRef]

29. Khlebnikov, A.I.; Schepetkin, I.A.; Domina, N.G.; Kirpotina, L.N.; Quinn, M.T. Improved quantitative structure-activity relationship models to predict antioxidant activity of flavonoids in chemical, enzymatic, and cellular systems. Bioorg. Med. Chem. 2007, 15, 1749-1770. [CrossRef]

30. Pignitter, M.; Schueller, K.; Burkon, A.; Knorr, V.; Esefelder, L.; Doberer, D.; Wolzt, M.; Somoza, V. Concentration-dependent effects of resveratrol and metabolites on the redox status of human erythrocytes in single-dose studies. J. Nutr. Biochem. 2016, 27, 164-170. [CrossRef]

31. Britton, R.G.; Kovoor, C.; Brown, K. Direct molecular targets of resveratrol: Identifying key interactions to unlock complex mechanisms. Ann. N. Y. Acad. Sci. 2015, 1348, 124-133. [CrossRef] [PubMed]

32. Hannaford, J.; Guo, H.; Chen, X. Involvement of cathepsins B and L in inflammation and cholesterol trafficking protein NPC2 secretion in macrophages. Obesity (Silver Spring) 2013, 21, 1586-1595. [CrossRef] [PubMed]

33. Burger, M.C.; Fernandes, J.B.; da Silva, M.F.; Escalante, A.; Prudhomme, J.; Le Roch, K.G.; Izidoro, M.A.; Vieira, P.C. Structures and bioactivities of dihydrochalcones from Metrodorea stipularis. J. Nat. Prod. 2014, 77, 2418-2422. [CrossRef]

34. Watanabe, M.; Kasai, M.; Tomizawa, H.; Aoki, M.; Eiho, K.; Isobe, Y.; Asano, S. Dihydropyrrolo[2,3-d]pyrimidines: Selective Toll-Like Receptor 9 Antagonists from Scaffold Morphing Efforts. ACS Med. Chem. Lett. 2014, 5, 1235-1239. [CrossRef]

35. Tsai, K.C.; Teng, L.W.; Shao, Y.M.; Chen, Y.C.; Lee, Y.C.; Li, M.; Hsiao, N.W. The first pharmacophore model for potent NF-kappaB inhibitors. Bioorg. Med. Chem. Lett. 2009, 19, 5665-5669. [CrossRef]

36. Gasparik, V.; Daubeuf, F.; Hachet-Haas, M.; Rohmer, F.; Gizzi, P.; Haiech, J.; Galzi, J.L.; Hibert, M.; Bonnet, D.; Frossard, N. Prodrugs of a CXC Chemokine-12 (CXCL12) Neutraligand Prevent Inflammatory Reactions in an Asthma Model in Vivo. ACS Med. Chem. Lett. 2012, 3, 10-14. [CrossRef] 
37. Ley, J.P.; Blings, M.; Paetz, S.; Krammer, G.E.; Bertram, H.J. New bitter-masking compounds: Hydroxylated benzoic acid amides of aromatic amines as structural analogues of homoeriodictyol. J. Agric. Food Chem. 2006, 54, 8574-8579. [CrossRef]

38. Ley, J.P.; Dessoy, M.; Paetz, S.; Blings, M.; Hoffmann-Lucke, P.; Reichelt, K.V.; Krammer, G.E.; Pienkny, S.; Brandt, W.; Wessjohann, L. Identification of enterodiol as a masker for caffeine bitterness by using a pharmacophore model based on structural analogues of homoeriodictyol. J. Agric. Food Chem. 2012, 60, 6303-6311. [CrossRef]

39. Choi, K.W.; Um, S.H.; Kwak, J.H.; Park, H.J.; Kim, K.H.; Moon, E.Y.; Kwon, S.T.; Pyo, S. Suppression of adhesion molecule expression by phenanthrene-containing extract of bulbils of Chinese Yam in vascular smooth muscle cells through inhibition of MAPK, Akt and NF-kappaB. Food Chem. Toxicol. 2012, 50, 2792-2804. [CrossRef]

40. Homma, M.; Minami, M.; Taniguchi, C.; Oka, K.; Morita, S.; Niitsuma, T.; Hayashi, T. Inhibitory effects of lignans and flavonoids in saiboku-to, a herbal medicine for bronchial asthma, on the release of leukotrienes from human polymorphonuclear leukocytes. Planta Med. 2000, 66, 88-91. [CrossRef]

41. Rimando, A.M.; Suh, N. Biological/chemopreventive activity of stilbenes and their effect on colon cancer. Planta Med. 2008, 74, 1635-1643. [CrossRef] [PubMed]

42. Elliger, C.A. Deoxygenation of Aldehydes and Ketones with Sodium Cyanoborohydride. Synthetic Commun. 1985, 15, 1315-1324. [CrossRef]

Sample Availability: Samples of the compounds are not available from the authors. Most compounds (1-5, 7-9, 12-14, 17 and 18) are commercially available. However, the authors described the preparation of the commercially non-available compounds $(6,10,11,15$ and 16) in the appendix to allow other researchers the repreparation of these compounds.

(C) 2020 by the authors. Licensee MDPI, Basel, Switzerland. This article is an open access article distributed under the terms and conditions of the Creative Commons Attribution (CC BY) license (http://creativecommons.org/licenses/by/4.0/). 